\title{
Growth Factor Midkine Promotes T-Cell Activation through Nuclear Factor of Activated T Cells Signaling and Th1 Cell Differentiation in Lupus Nephritis
}

Tomohiro Masuda, ${ }^{* \dagger}$ Kayaho Maeda, ${ }^{*}$ Waichi Sato, ${ }^{*}$ Tomoki Kosugi, ${ }^{*}$ Yuka Sato, ${ }^{*}$ Hiroshi Kojima, ${ }^{*}$ Noritoshi Kato, * Takuji Ishimoto, ${ }^{*}$ Naotake Tsuboi, ${ }^{*}$ Kenji Uchimura, ${ }^{\dagger}$ Yukio Yuzawa, ${ }^{\dagger}$ Shoichi Maruyama, ${ }^{*}$ and Kenji Kadomatsu ${ }^{\dagger}$

From the Departments of Nephrology* and Biochemistry, ${ }^{\dagger}$ Nagoya University Graduate School of Medicine, Nagoya; and the Department of Nephrology, ${ }^{\ddagger}$ Fujita Health University School of Medicine, Toyoake, Japan

Accepted for publication

December 8, 2016.

Address correspondence to Tomoki Kosugi, M.D., Ph.D., Department of Nephrology, Nagoya University Graduate School of Medicine, 65 Tsurumaicho, Showa-ku, Nagoya 466-8550, Japan. E-mail: kosugi@med.nagoya-u.ac.jp.

\begin{abstract}
Activated T cells play crucial roles in the pathogenesis of autoimmune diseases, including lupus nephritis (LN). The activation of calcineurin/nuclear factor of activated T cells (NFAT) and STAT4 signaling is essential for T cells to perform various effector functions. Here, we identified the growth factor midkine (MK; gene name, Mdk) as a novel regulator in the pathogenesis of 2,6,10,14-tetramethylpentadecaneinduced LN via activation of NFAT and IL-12/STAT4 signaling. Wild-type $\left(\mathrm{Mdk}^{+/+}\right)$mice showed more severe glomerular injury than MK-deficient $\left(\mathrm{Mdk}^{-/-}\right)$mice, as demonstrated by mesangial hypercellularity and matrix expansion, and glomerular capillary loops with immune-complex deposition. Compared with $M d k^{-/-}$mice, the frequency of splenic $\mathrm{CD} 69^{+} \mathrm{T}$ cells and Thelper (Th) 1 cells, but not of regulatory $\mathrm{T}$ cells, was augmented in $M d k^{+/+}$mice in proportion to $\mathrm{LN}$ disease activity, and was accompanied by skewed cytokine production. MK expression was also enhanced in activated $\mathrm{CD}^{+}{ }^{+} \mathrm{T}$ cells in vivo and in vitro. MK induced activated $\mathrm{CD}^{+}{ }^{+} \mathrm{T}$ cells expressing $\mathrm{CD} 69$ through nuclear activation of NFAT transcription and selectively increased in vitro differentiation of naive $\mathrm{CD}^{+}{ }^{+}$T cells into Th1 cells by promoting IL-12/STAT4 signaling. These results suggest that MK serves an indispensable role in the NFAT-regulated activation of $\mathrm{CD}^{+} \mathrm{T}$ cells and Th1 cell differentiation, eventually leading to the exacerbation of LN. (Am J Pathol 2017, 187: 740-751; http://dx.doi.org/10.1016/j.ajpath.2016.12.006)
\end{abstract}

Lupus nephritis (LN) is one of the critical determinants for mortality and morbidity of systemic lupus erythematosus (SLE). ${ }^{1,2} \mathrm{~T}$ lymphocytes, which play crucial roles in adaptive immune responses, contribute to the initiation and perpetuation of autoimmunity in SLE. ${ }^{3,4}$ In this setting, a variety of cytokines and chemokines that they produce are involved in the pathogenesis of LN. ${ }^{5}$ During T-cell activation, these genes are regulated by calcium signaling calcineurin $(\mathrm{Cn})$-dependent transcription factor, nuclear factor of activated $\mathrm{T}$ cells (NFAT) together with other signaling pathways. ${ }^{6-9}$ Given the prominent role of NFAT proteins in the regulation of T-cell activation, NFAT is considered to be an optimal target for therapeutic approaches to autoimmune diseases. Once self-tolerance is broken, the skewed profile of cytokine expression causes activation of $\mathrm{T}$ helper (Th) cell subsets, including Th1, Th17, and regulatory $\mathrm{T}$ cells (Tregs), through the dysfunction of STAT signaling, leading to the disruption of their reciprocal relation in autoimmunity. ${ }^{1,10}$ Therefore, an enhanced understanding of adaptive immune activation and regulation of tolerance is required for novel therapeutic strategies.

The growth factor midkine (MK; gene name, $M d k$ ) is suggested to have major biological roles, including roles in promoting cell proliferation, cell survival, and the migration of various cells, and it also displays antiapoptotic activity. ${ }^{11,12}$ Its main actions can be categorized into three areas: the nervous system, cancer, and inflammation. ${ }^{13}$ To date, the neuronal protective effects of MK were investigated in in vivo studies such as in cerebral infarction and ischemia-induced

Supported in part by a grant-in-aid for Progressive Renal Diseases Research, Research on Rare and Intractable Disease, Nephrology Research from the Ministry of Health Labor and Welfare of Japan (90584681; T.K.).

Disclosures: None declared. 
neuronal death. ${ }^{14,15}$ In a series of prior studies, we generated mice deficient in the $M d k$ gene $\left(M d k^{--}\right)$and used them to demonstrate that $\mathrm{MK}$ is involved in inflammation through cytokine induction and modulation of the migration of neutrophils and macrophages in arterial restenosis, rheumatoid arthritis, ischemic renal injury, and diabetic nephropathy. ${ }^{16-20}$ Besides their elicitation via chemotactic activity, MK also serves as a negative immune modulator of Tregs in peripheral lymph nodes. Inhibition of MK caused enhanced Treg expansion and subsequently suppressed autoreactive Th1 cell populations, eventually leading to attenuation of the severity of experimental autoimmune encephalomyelitis similar to multiple sclerosis. ${ }^{21,22}$ It is well recognized that IL-2 signaling is essential for the development and function of Tregs, a potent regulator of T-cell subset. Although IL-2 is induced in the development of experimental autoimmune encephalomyelitis, the exacerbation of $\mathrm{LN}$ shows a reduction in IL2 transcription with dysfunction of Tregs. ${ }^{23,24}$ The involvement of MK in the molecular mechanism of LN has not yet been elucidated in detail.

We therefore conducted the present study to investigate the role of MK in the pathogenesis of LN. Notably, MK expressed in splenic $\mathrm{CD} 4{ }^{+} \mathrm{T}$ cells positively regulated Treg-independent differentiation into Th 1 cells in active $\mathrm{LN}$. To understand these phenomena, a detailed explanation of how the activation and differentiation of T-cell subsets in $\mathrm{LN}$ are orchestrated by MK is required. We demonstrated that activation of $\mathrm{CD} 4^{+} \mathrm{T}$ cells accompanies the secretion of $\mathrm{MK}$ that is responsible for skewed cytokine production, which, in turn, enhances splenicactivated $\mathrm{CD}^{+}{ }^{+} \mathrm{T}$ cells expressing CD69 through the induction of NFAT-mediated gene transcription. In this setting, the altered cytokine profile further promotes the expansion and differentiation of Th1 cells through IL-12/STAT4 signaling. The obtained results enabled an understanding of the potent role of $\mathrm{MK}$ in the activation of T cells in autoimmune diseases through amplification of a physiological loop.

\section{Materials and Methods}

\section{Animals and Experimental Design}

$M d k^{-/-}$mice were generated as described previously. ${ }^{25}$ After backcrossing of $M d k^{+/-}$mice for 20 generations with 129/SV mice, $M d k^{+l-}$ mice were mated with each other to generate $M d k^{+/+}$and $\mathrm{Mdk}^{-/-}$mice that were used in this study. Experiments were performed with 8- to 12-week-old female mice weighing 20 to $25 \mathrm{~g}$, and mice were housed under controlled environmental conditions and maintained with standard food and water. LN was induced in $\mathrm{Mdk}^{+/+}$and $M d k^{-/-}$mice with an intraperitoneal injection of TMPD (pristane; 2,6,10,14-tetramethylpentadecane; $0.5 \mathrm{~mL} /$ mouse) as described previously. ${ }^{26}$ Mice were sacrificed at 6 months after treatment. MRL/lpr female mice were purchased from Japan SLC, Inc. (Shizuoka, Japan) and then were sacrificed at 3 months after birth. Kidneys and the spleen were removed for examination. All of the animal experiments were performed in accordance with the animal experimentation guidelines of Nagoya University School of Medicine.

\section{Histologic Examination}

Kidney tissues were fixed in $10 \%$ formalin, embedded in paraffin, and then cut into $2-\mu \mathrm{m}-$ thick sections. Sections stained with hematoxylin and eosin and periodic acid-Schiff were used for morphometric analysis of the activity indices of human LN as described previously. ${ }^{27,28}$ In brief, the extent of kidney injury was determined by assessing histologic features reflective of LN activity such as endocapillary hypercellularity, leukocyte infiltration, subendothelial hyaline deposits, fibrinoid necrosis/karyorrhexis, cellular crescent, and interstitial inflammation. All of the quantifications were performed in a blinded manner by two independent expert nephropathologists (K.M. and W.S.).

Parts of the kidney tissues were snap-frozen in liquid nitrogen. Sections $(4 \mu \mathrm{m}$ thick) were cut with a cryostat and fixed with acetone. The sections were stained with rat antimouse IgG antibody (Ab) (Life Technologies, Carlsbad, CA), C3 Ab (Abcam, Cambridge, United Kingdom), Clq mouse Ab (Abcam), or CD68 Ab (AbD Serotec, Oxford, United Kingdom), followed by detection with fluorescein isothiocyanate-conjugated rabbit anti-rat $\mathrm{IgG} \mathrm{Ab}$ (Zymed Laboratories, San Francisco, CA). The sections were stained with anti-CD3 Ab (Abcam) or rat anti-mouse CD4 Ab (Abcam), followed by biotin-conjugated rabbit anti-rat $\mathrm{Ab}$ (Nichirei, Tokyo, Japan). Staining was visualized with 3, 3'diaminobenzidine (Dako, Carpinteria, CA), which produced a brown color. Negative controls involved replacement of the primary Abs with species-matched Abs. Leukocytes positive for $\mathrm{CD} 3, \mathrm{CD} 4$, or CD68 in the glomerulus of all renal regions were counted under a microscope in a blind manner. For electron microscopic analysis, kidneys were fixed in formalin, embedded in epoxy resin, and stained with uranyl acetate and lead citrate.

Biochemical Examination, Autoantibody Analysis, and IL-2 Measurement

The ratio of albumin to creatinine in urine was measured as described previously. ${ }^{29}$ The hallmarks of LN activity were determined using enzyme-linked immunosorbent assay methods, according to the manufacturers' instructions (IgG1, G2a, and G2b; R\&D Systems Inc., Minneapolis, MN; anti-single-stranded DNA $\mathrm{Ab}$ and anti-double-stranded DNA Ab, Shibayagi, Gunma, Japan). The IL-2 levels in the supernatant fluid of cultured $\mathrm{T}$ splenocytes were measured with an enzyme-linked immunosorbent assay kit (Thermo Fisher Scientific Inc., Waltham, MA).

\section{Flow Cytometric Analysis}

Splenocytes or renal cells were blocked with saturating amounts of anti-CD16/32 Abs (BD Biosciences, San Diego, $\mathrm{CA}$ ) and were then stained with the following conjugated 
Abs: fluorescein isothiocyanate/allophycocyanin (APC) rat anti-mouse $\mathrm{CD} 3 \mathrm{e}$, fluorescein isothiocyanate/APC/phycoerythrin (PE)-cyanine 7 rat anti-mouse $\mathrm{CD} 4, \mathrm{PE}$ rat antimouse CD8a, IL-4, IL-17, CD45R/B220, IgM, CD44, and CD25; APC rat anti-mouse interferon (IFN) $\gamma$, CD138, IgD, and CD62L; Alexa Fluor 488 rat anti-mouse FoxP3, and APC/PE-cyanine 7 rat anti-mouse CD69 (BioLegend, San Diego, CA). Cells were acquired with a FACSCanto II flow cytometer (BD Biosciences).

\section{Real-Time PCR}

Mouse kidney tissues were snap-frozen in liquid nitrogen for total mRNA isolation as described previously. ${ }^{30}$ Real-time PCR analysis was performed with an Applied Biosystems Prism 7500HT sequence detection system, using TaqMan gene expression assays (Applied Biosystems, Foster City, CA). TaqMan probes and primers for tumor necrosis factor- $\alpha$ (Celf2 Mm01336295_m1), IL-1 $\beta$ (Il1 $\beta$ Mm00434228_m1), IL-6 (Il6st Mm00439665_m1), IFN- $\gamma$ (Pglyrp2 Mm01348077_m1), monocyte chemoattractant protein 1 (Ccl2 Mm00441242_m1), and glyceraldehyde-3phosphate dehydrogenase (Gapdh Mm99999915_m1) were used. Amplification data were analyzed with Applied Biosystems Sequence Detection software version 1.3.1.

\section{Western Blot Analysis}

Mouse kidney and spleen tissues were snap-frozen in liquid nitrogen for protein isolation and were then lyzed in a radioimmunoprecipitation assay buffer (Santa Cruz Biotechnology, Dallas, TX). Lymphocytes from in vitro studies were lyzed with the NE-PER Nuclear and Cytoplasmic Extraction Reagent Kit (ThermoFisher Scientific Inc.). Western blot analysis was performed as described previously. ${ }^{31}$ The blots were incubated with goat-anti-mouse $\mathrm{MK} \mathrm{Ab},{ }^{32}$ monoclonal anti- $\beta$-actin Ab (Sigma-Aldrich, St. Louis, MO), rabbit-anti-mouse NFAT1 Ab, histone-H3 Ab, glyceraldehyde-3-phosphate dehydrogenase Ab, STAT1 Ab, phosphoSTAT1 Ab, STAT4 Ab (all from Cell Signaling Technology, Danvers, MA), and phospho-NFATc2 Ab (Santa Cruz Biotechnology); and mouse monoclonal anti-mouse phospho-STAT4 Ab (Santa Cruz Biotechnology), followed by incubation with peroxidase-conjugated anti-goat IgG, mouse $\mathrm{IgG}$, and rabbit IgG (Jackson Immunoresearch Laboratories, West Grove, PA). The protein signals were visualized with an Amersham Imager 600 (GE Healthcare, Little Chalfont, United Kingdom).

\section{Intracellular Staining and T-Cell Differentiation Assessment}

Splenocytes were restimulated for 5 hours with $50 \mathrm{ng} / \mathrm{mL}$ phorbol myristate acetate (Sigma-Aldrich) and $1 \mu \mathrm{g} / \mathrm{mL}$ ionomycin (Sigma-Aldrich) along with brefeldin A (BD Biosciences). After surface staining with the indicated Abs, the cells were fixed with Fixation/Permeabilization Buffer (BD Biosciences), permeabilized with Perm/Wash Buffer (BD Biosciences), and stained with the following conjugated Abs: APC rat-anti-mouse IFN- $\gamma$, PE rat-anti-mouse IL-4, APC rat-anti-mouse IL-17, PE rat-anti-mouse IL-17, AF488 rat-anti-mouse Foxp3 (BD Biosciences).

Naive $\mathrm{CD} 4{ }^{+} \mathrm{CD}_{2} \mathrm{~L}^{+} \mathrm{T}$ cells were isolated from the spleen as described previously. ${ }^{26}$ Purified cells were cultured in RPMI 1640 (Sigma-Aldrich), supplemented with 10\% fetal bovine serum and $2 \mathrm{mmol} / \mathrm{L}$ L-glutamine, and were then activated with anti-CD3 and anti-CD28 Abs (Life Technologies) for 3 days with the following cytokines and neutralizing Abs for the desired polarization: $10 \mathrm{ng} / \mathrm{mL} \mathrm{IL-12}$ (R\&D Systems) and $10 \mu \mathrm{g} / \mathrm{mL}$ anti-IL-4 (BioLegend) for Th1 cell polarization; $50 \mathrm{ng} / \mathrm{mL}$ IL-4, $200 \mathrm{U} / \mathrm{mL}$ IL-2 (R\&D Systems), and $10 \mu \mathrm{g} / \mathrm{mL}$ anti-IFN- $\gamma$ (BioLegend) for Th2 cell polarization; $1 \mathrm{ng} / \mathrm{mL}$ transforming growth factor- $\beta, 50 \mathrm{ng} / \mathrm{mL} \mathrm{IL}-6$ (R\&D Systems), $5 \mathrm{ng} / \mathrm{mL}$ IL-23 (BioLegend), $10 \mu \mathrm{g} / \mathrm{mL}$ anti-IFN- $\gamma$, and $10 \mu \mathrm{g} / \mathrm{mL}$ anti-IL-4 for Th17 cell polarization; $5 \mathrm{ng} / \mathrm{mL}$ transforming growth factor- $\beta, 200 \mathrm{U} / \mathrm{mL}$ IL2 , and $10 \mu \mathrm{g} / \mathrm{mL}$ anti-IFN- $\gamma$ for Treg cell polarization.

\section{Statistical Analysis}

All values are expressed as means \pm SEM. Statistical analyses were performed with an unpaired $t$-test or the nonparametric $U$ test for single comparisons or analysis of variance for multiple comparisons. Post hoc least significant difference tests were performed if the initial analysis of variance was significant. $P<0.05$ was considered significant.

\section{Results}

\section{MK Deficiency Ameliorates Glomerular Injury in LN}

To investigate the role of MK in the pathogenesis of $\mathrm{LN}$, we evaluated the degree of glomerular injury in $\mathrm{Mdk}^{+/+}$and $M d k^{-1-}$ mice at 6 months after TMPD treatment. No obvious differences between the two genotypes were found in kidney and body weight or renal function (Table 1). The spleen weight (Table 1) and total numbers of splenocytes (data not shown) tended to be higher in $\mathrm{Mdk}^{+/+} \mathrm{LN}$ mice

Table 1 General Characteristics of the Mice Analyzed in This Study

\begin{tabular}{llll}
\hline Mouse type & Bwt & Kidney, g & Spleen, g \\
\hline$M d k^{+/+}$(TMPD) & $29.8 \pm 1.9$ & $0.41 \pm 0.09$ & $0.39 \pm 0.30$ \\
$M d k^{-/-}$(TMPD) & $26.8 \pm 1.4$ & $0.34 \pm 0.03$ & $0.18 \pm 0.12$ \\
$M d k^{+/+}$(No Rx) & $32.0 \pm 1.5$ & $0.34 \pm 0.02$ & $0.11 \pm 0.07$ \\
$M d k^{-/-}$(No Rx) & $28.8 \pm 0.9$ & $0.35 \pm 0.08$ & $0.08 \pm 0.08$ \\
\hline
\end{tabular}

Data are expressed as means \pm SEM.

Bwt, body weight; $\mathrm{Mdk}^{-/-}$, midkine gene-deficient mice; $\mathrm{Mdk}^{+/+}$, wildtype mice; No Rx, no TMPD treatment; TMPD, 2,6,10,14tetramethylpentadecane. 
A

PAS
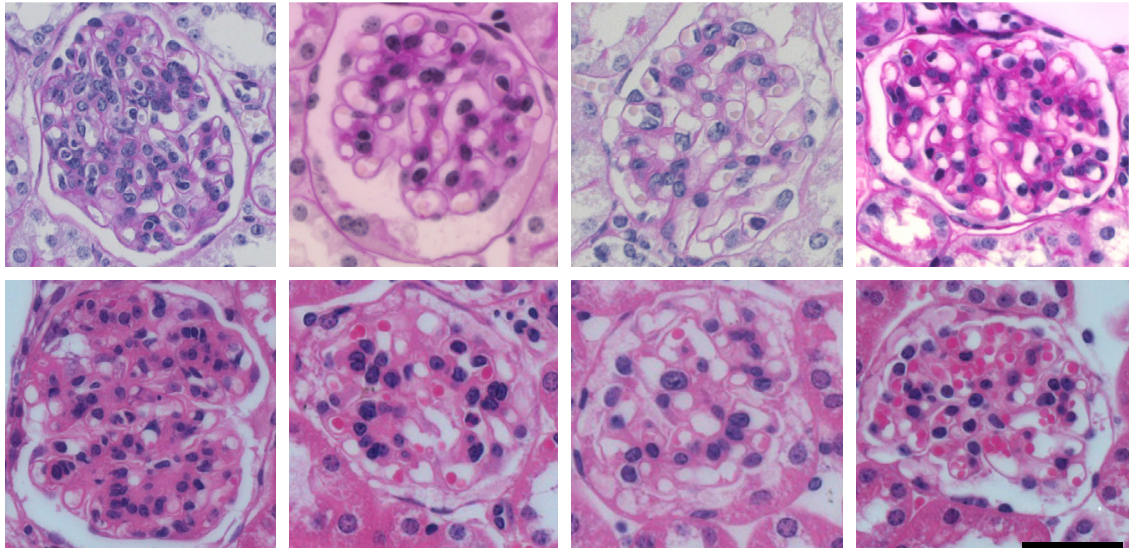

$M d k^{+/+}$

$M d k^{-}$

$M d k^{+/+}$

$M d k^{-/}$

TMPD

No Rx

B

IgG
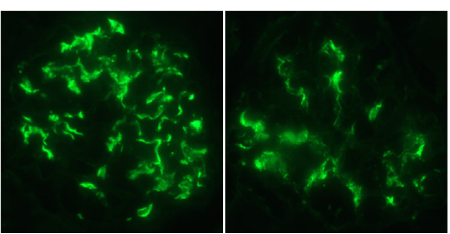

C3
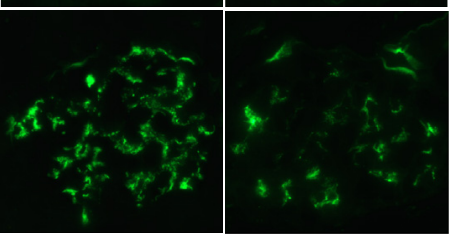

$\mathrm{Clq}$

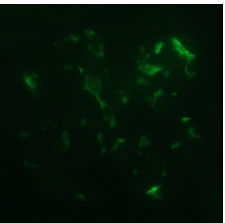

$M d k^{+/+}$

D

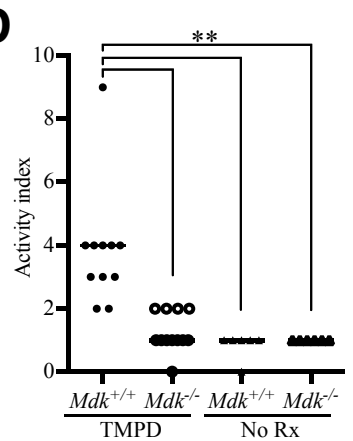

C

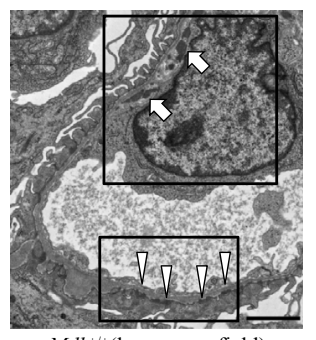

$M d k^{+/+}$(low power field)

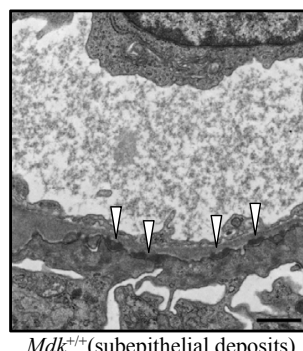

F

E

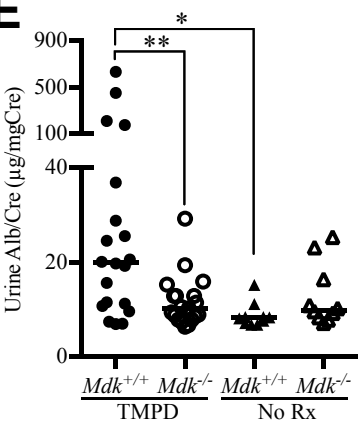

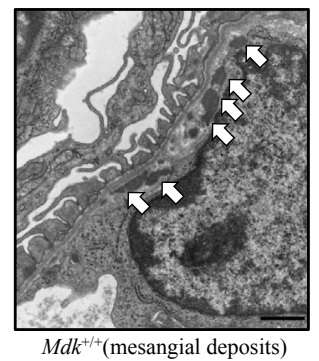

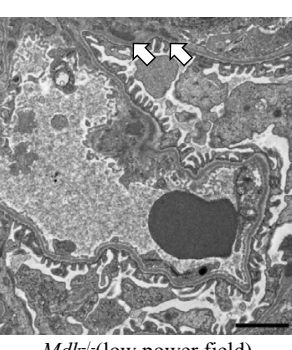

$M d k^{-/}$(low power field)

\section{G}
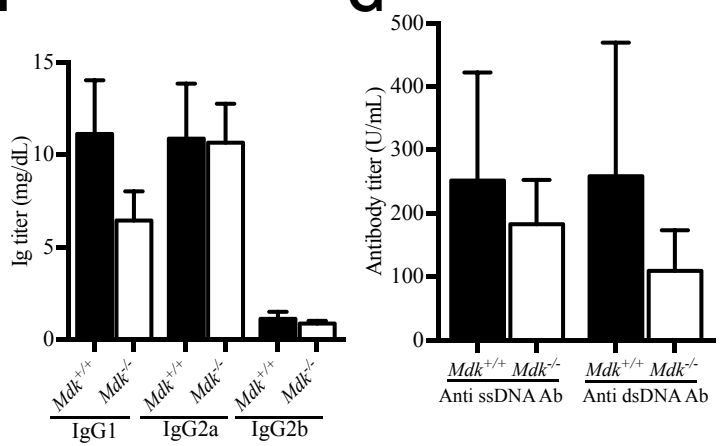

Figure 1 Midkine deficiency ameliorates lupus nephritis in vivo. A: Representative images of PAS- and HE-stained glomeruli at 6 months in wild-type $\left(\mathrm{Mdk}^{+/+}\right)$and in midkine-deficient $\left(\mathrm{Mdk}^{-/-}\right)$mice. B: Immunofluorescence staining of mouse IgG, mouse C3, and mouse C1q at 6 months after TMPD injection. C: Representative electron micrographs of the glomerulus at 6 months in $M d k^{+/+}$and $M d k^{-1-}$ mice. Arrow, mesangial immune-complex deposition; arrowhead, subepithelial immune-complex deposition. D: The lupus nephritis activity index (range, 0-24) at 6 months after TMPD injection. E: The urine albumin-creatinine (Alb/Cre) ratio at 6 months. F: Serum IgG1, IgG2a, and IgG2b titers. Closed columns, $\mathrm{Mdk}^{+/+}$; open columns, Mdk ${ }^{-/-}$. G: Serum anti-ssDNA $A b$ and anti-dsDNA $A b$ titers at 6 months. Data are expressed as values for individual mice and median values (D and $\mathbf{E})$ or means \pm SEM $(\mathbf{F}$ and $\mathbf{G}) . n=11$ each TMPD treatment (D); $n=6$ no $\operatorname{Rx}(\mathbf{D}) ; n=6(\mathbf{E}) .{ }^{*} P<0.05,{ }^{*} P<0.01$. Scale bars: $50 \mu \mathrm{m}(\mathbf{A}$ and B); $2.0 \mu \mathrm{m}$ (C, left top, right bottom); $1.0 \mu \mathrm{m}(\mathbf{C}$, right top, left bottom). Ab, antibody; dsDNA, double-stranded DNA; HE, hematoxylin and eosin; No Rx, no TMPD treatment; PAS, periodic acid-Schiff; ssDNA, single-stranded DNA; TMPD, 2,6,10,14-tetramethylpentadecane. 
than in $M d k^{-1-}$ mice. Basically, TMPD caused only mild glomerular damage but not tubulointerstitial injury. $M d k^{+/+}$ mice showed more severe glomerular injury than $M d k^{-l-}$ mice, as demonstrated by mesangial hypercellularity and matrix expansion, and glomerular capillary loops with immune-complex deposition (Figure 1A). In immunofluorescence analysis of the glomeruli and higher deposition of $\mathrm{IgG}, \mathrm{C} 3$, and $\mathrm{C} 1 \mathrm{q}$ was observed in the mesangial areas and partly in the capillary loop of $M d k^{+/+}$mice compared with $M d k^{-1-}$ mice (Figure 1B). Consistent with the profiles of immunofluorescence analysis, increase of immune-complex deposition was observed in $M d k^{+/+}$mice more than in $M d k^{-1-}$ mice, using electron microscopy (Figure 1, B and C). Interestingly, the involvement of immune-complex deposition in subepithelial areas was absent in $M d k^{-I-}$ mice. The histologic investigations shown in Figure 1A were complemented by morphologic assessment of the activity index for human LN. The profile of the activity index of LN was consistent with the pathologic findings (Figure 1, A-D). The index was not enhanced in $M d k^{-l}$ mice at 6 months after treatment, compared with agematched mice without treatment. Albuminuria was also greater in $M d k^{+/+}$mice than in $M d k^{-/-}$mice (Figure 1E). No obvious difference between $M d k^{+/+}$and $M d k^{-/-}$mice was observed in the tubular interstitium (data not shown). These results suggest that MK deficiency suppressed the degree of glomerular injury and LN disease activity after TMPD treatment.

Because enhanced humoral autoimmunity is required for the progression of $\mathrm{LN}$, we also examined $\mathrm{IgG}$ values of the mice. TMPD treatment increased the titers of IgG subtypes in both genotypes, but the differences between the two genotypes were not significant (Figure 1F). Likewise, the profiles of autoantibody values specifically directed against single-stranded DNA and double-stranded DNA tended to be increased in lupus $M d k^{+/+}$mice, but the differences between the two genotypes were not significant (Figure 1G).

Infiltrating Inflammatory Cells Are Less Marked in the Glomeruli of $\mathrm{Mdk}^{-/-}$Mice Than in $\mathrm{Mdk}^{+/+}$Mice

There is growing evidence for the participation of inflammatory cells in $\mathrm{LN}^{1,2}$ and for the chemotactic activity of MK. ${ }^{12}$ To determine which subsets of leukocytes are induced by MK after TMPD treatment, we assessed the recruitment of inflammatory cells to the lupus kidneys. Infiltrating $\mathrm{CD}^{+}, \mathrm{CD}^{+}$, and $\mathrm{CD}^{+} 8^{+}$cells were more prominent in the glomeruli of $\mathrm{Mdk}^{+/+}$mice than in the glomeruli of $M d k^{-I-}$ mice (Figure 2, A and B). TMPD treatment significantly augmented $\mathrm{CD} 3{ }^{+} \mathrm{CD} 69^{+}$, $\mathrm{CD} 4{ }^{+} \mathrm{CD} 69^{+}$, and $\mathrm{CD} 4{ }^{+} \mathrm{CD} 45^{+} \mathrm{IFN}-\gamma^{+}$cells in the lupus kidneys of $M d k^{+/+}$mice compared with $M d k^{-/-}$mice, determined by flow cytometric technique (Figure 2, C-G). These data suggest that effector $\mathrm{T}$ cells as well as M1 macrophages were higher in the lupus kidney of $M d k^{+/+}$ mice than in $M d k^{-1-}$ mice. In support of these data and consistent with previous reports, ${ }^{5,26}$ high expression of inflammation-related molecules, including tumor necrosis factor- $\alpha$, IL- $1 \beta$, IL- 6 , and monocyte chemoattractant protein 1 , was observed in lupus $M d k^{+/+}$kidneys. The expression of these molecules was significantly higher in $M d k^{+/+}$than in $M d k^{-/-}$mice (Figure 2H). IFN- $\gamma$ levels tended to be higher in lupus $M d k^{+/+}$mice than in $M d k^{-/-}$ mice. No obvious differences between the two genotypes were found in the frequency of $\mathrm{CD} 4{ }^{+} \mathrm{CD} 45^{+} \mathrm{IL}-17^{+}$ cells (Figure 2G), Tregs, or in the expression of IL-17 (data not shown).

\section{MK Deficiency Suppresses the Activation of Splenic T Lymphocytes in Vivo}

In general, $\mathrm{T}$ lymphocytes derived from the spleen play an important role in the development of LN. ${ }^{1,3}$ We therefore analyzed the expression of the T-cell-activation markers CD69, CD62L, and CD44 in CD4 ${ }^{+}$splenocytes in TMPDinduced $M d k^{+/+}$and $M d k^{-/-}$mice. Compared with $M d k^{-1-}$ mice, the percentage of splenic $\mathrm{CD}^{+} \mathrm{CD} 69^{+}$and $\mathrm{CD} 4{ }^{+} \mathrm{CD} 44^{+} \mathrm{CD}_{2} \mathrm{~L}^{-}$cells in $M d k^{+/+}$mice was higher, whereas the percentage of naive $\mathrm{CD} 4{ }^{+} \mathrm{CD} 44^{-} \mathrm{CD}_{2} 2 \mathrm{~L}^{+} \mathrm{T}$ cells was decreased (Figure 3, A-C). The profiles of activated $\mathrm{T}$ lymphocytes in the spleens were compatible with those of the kidneys. A striking increase in MK expression was found in $M d k^{+/+}$spleens at 6 months after TMPD treatment (Figure 3, D and E). Flow cytometric profiles of $\mathrm{CD}^{+}$and $\mathrm{CD}^{+}$cells did not show any differences between the two genotypes (data not shown). In addition, Tcell development in the thymus was unchanged by the presence of MK (data not shown). Because T-cell subsets show inappropriate tissue homing in SLE, ${ }^{2,33}$ the differentiation of Th cell subsets in the lupus spleen was therefore examined. Consistent with the profiles of renal T lymphocytes, the frequency and the number of Th1 cells were significantly enhanced in TMPD-induced $\mathrm{Mdk}^{+/+}$splenocytes compared with $\mathrm{Mdk}^{--}$splenocytes (Figure $2 \mathrm{G}$ and Figure 3, F and G). The number but not the frequency of Th17 cells was also increased after TMPD treatment. No significant differences were seen in the frequency and number of Tregs between TMPD-treated $\mathrm{Mdk}^{+/+}$and $M d k^{-1-}$ spleens. No obvious differences were observed in the percentage of mature $\mathrm{CD} 138^{+} \mathrm{B} 220^{+}$, immature $\mathrm{IgD}^{+} \operatorname{IgM}^{-} \mathrm{B} 220^{+}$, and $\operatorname{IgD}^{+} \operatorname{IgM}^{+} \mathrm{B} 220^{+}$B cells between the two genotypes (Figure $3 \mathrm{H}$ ). The collective data supported the idea that MK induction was associated with the activation of T cells in TMPD-induced LN mice, particularly of Th1 cells, but was not associated with differentiation of Tregs.

\section{MK Promotes NFAT1-Mediated T-Cell Activation and Th1 Cell Differentiation in Splenocytes in Vitro}

To further clarify the involvement of MK in the activation and differentiation of $\mathrm{T}$ cells, we next assessed MK 

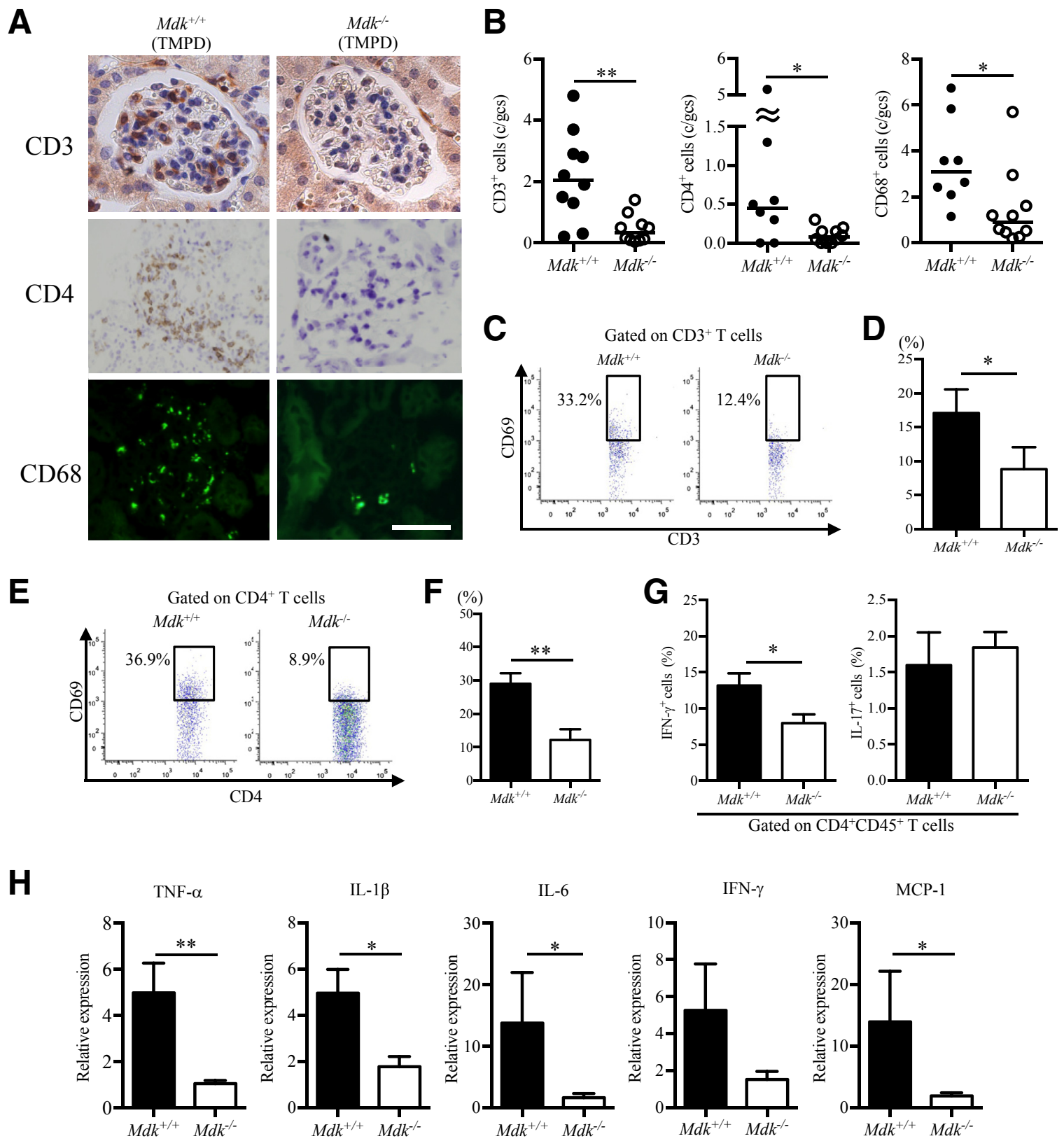

Figure 2 Midkine deficiency prevents the infiltration of inflammatory cells into the lupus kidney. A: Immunohistochemical staining of $\mathrm{CD} 3^{+}, \mathrm{CD}^{+}$, and immunofluorescence staining of $\mathrm{CD} 68^{+}$cells in the TMPD-induced lupus kidney. B: The numbers of $\mathrm{CD3}^{+}, \mathrm{CD}^{+}$, and $\mathrm{CD} 68^{+}$cells in glomeruli. C: Representative $\mathrm{CD} 69$ staining profiles of gated $\mathrm{CD}^{+}{ }^{+}$cells in lupus mice assessed using flow cytometry. D: Percentage of renal $\mathrm{CD}^{+} \mathrm{CD}^{+} 9^{+}$cells in C. Black columns, Mdk ${ }^{+/+}$; white columns, $\mathrm{Mdk}^{-/-}$. E: Representative CD69 staining profiles of gated $\mathrm{CD}^{+}{ }^{+} \mathrm{T}$ cells in lupus mice. F: Percentages of renal $\mathrm{CD}^{+} \mathrm{CD} 69^{+}$cells in $\mathrm{E}$. G: Percentages of renal $\mathrm{CD} 4{ }^{+} \mathrm{CD} 45^{+} \mathrm{IFN}-\gamma^{+}$(Th1) and $\mathrm{CD} 4^{+} \mathrm{CD} 45^{+} \mathrm{IL}_{17} 7^{+}$(Th17) cells in lupus mice. Renal T-cell subsets were determined by the profiles of intracellular cytokine expression, as described in the Materials and Methods. H: The mRNA expression of inflammation-related molecules in lupus kidneys. Data are expressed as values for individual mice and median values (B), percentages of $\mathrm{CD}^{+}{ }^{+} \mathrm{CD} 69^{+}$cells (C), or means $\pm \mathrm{SEM}(\mathbf{D}, \mathbf{F}$, and $\mathbf{G})$. $n=8$ to 10 (B and $\left.\mathbf{G}\right)$; $n=6(\mathbf{D}$ and $\mathbf{H}) .{ }^{*} P<0.01,{ }^{*} P<0.05$. Scale bar $=50 \mu \mathrm{m}(\mathbf{A}) . \mathrm{c} / \mathrm{gcs}$, count per glomerular cross section; IFN, interferon; MCP, monocyte chemoattractant protein; TMPD, 2,6,10,14-tetramethylpentadecane; TNF, tumor necrosis factor.

induction in activated T cells and the effect of MK on Th1 cell differentiation in vitro, using naive $\mathrm{CD}^{+}{ }^{+} \mathrm{T}$ cells from $M d k^{+/+}$or $M d k^{-/-}$spleens. Consistent with the profile of MK expression in vivo (Figure 3, D and E), a gradual increase in MK production in the supernatant fluid of cultured $\mathrm{CD}^{+} \mathrm{T}$ lymphocytes from $\mathrm{Mdk}^{+/+}$mice was observed during their activation mediated by anti-CD3/CD28 Abs (Figure 4A). MK protein expression in the lysate of activated $\mathrm{T}$ cells showed a similar profile (data not shown). To determine whether the difference in the frequency of activated T cells between $M d k^{+/+}$and $M d k^{-/-}$mice was due to the presence or absence of MK, we next examined the effect of addition of the MK protein to $M d k^{-/-}$activated T cells. The frequency of $\mathrm{CD} 4{ }^{+} \mathrm{CD} 69^{+}$cells in $M d k^{+/+}$ splenocytes exposed to anti-CD3/CD28 Abs was higher at 2 days after stimulation compared with $M d k^{-/-}$mice 
A

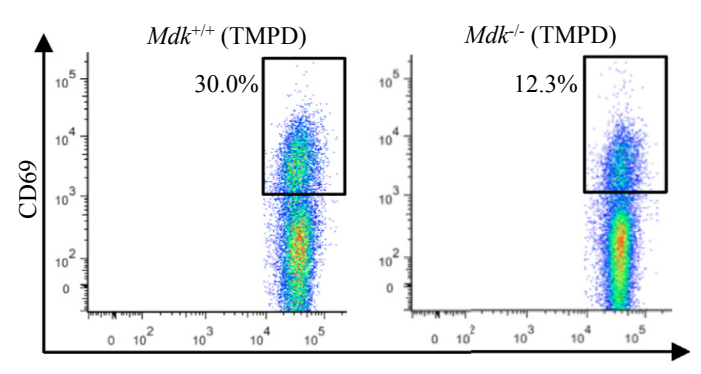

D

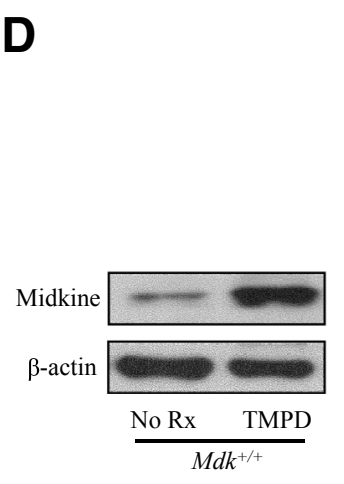

G

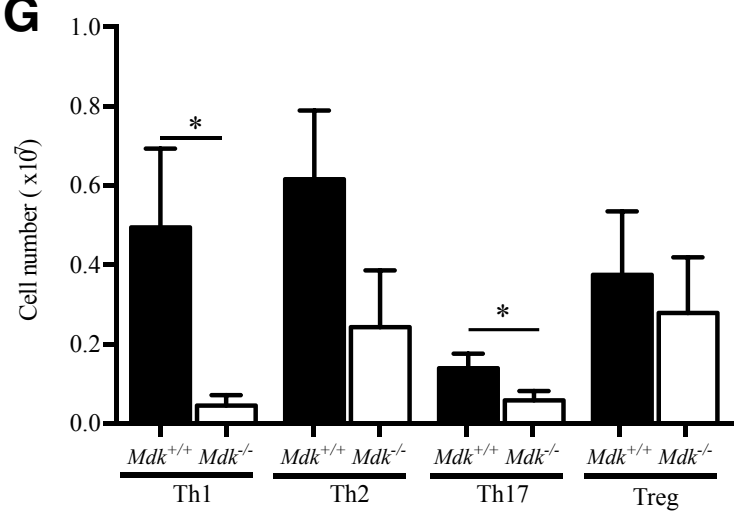

E

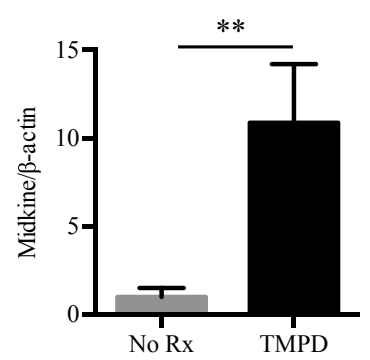

H
B

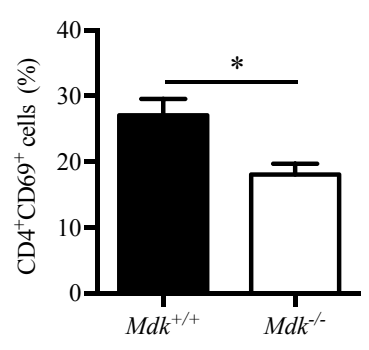

C

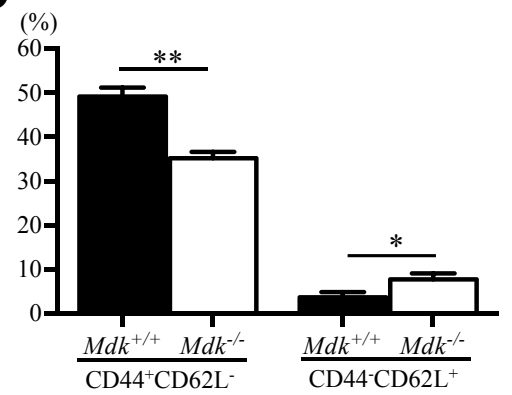

F

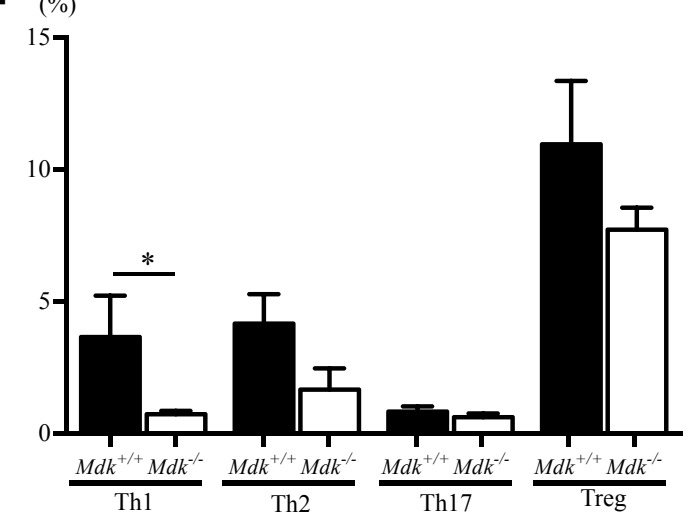

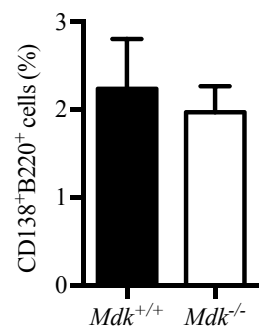
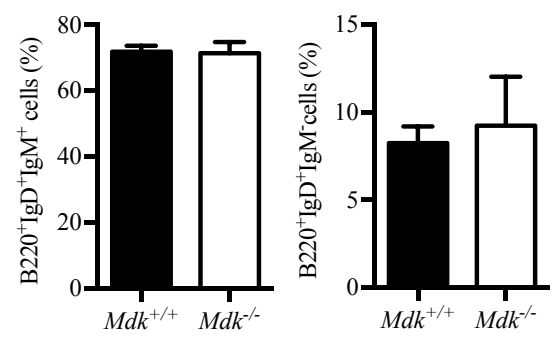

Figure $3 \mathrm{CD}^{+}$T cells from the spleens of TMPD-induced mice. A: Representative CD69 staining profiles of gated CD4 ${ }^{+} \mathrm{T}$ cells in lupus mice. B: Percentages of splenic $\mathrm{CD}^{+}{ }^{+} \mathrm{CD} 69^{+}$cells in A. Black columns, $\mathrm{Mdk}^{+/+}$; white columns, $\mathrm{Mdk}^{-/-}$. C: Percentage of $\mathrm{CD} 62 \mathrm{~L}^{+} \mathrm{CD} 44^{-} \mathrm{CD}^{+}$and $\mathrm{CD} 62 \mathrm{~L}^{-} \mathrm{CD} 44^{+} \mathrm{CD} 4^{+}$T cells in the spleens of lupus $\mathrm{Mdk}^{+/+}$or $\mathrm{Mdk}^{-/-}$mice. D: MK expression in the spleen at 6 months determined by Western blot analysis. E: The intensities of the MK bands that were normalized to $\beta$-actin. Gray columns, Mdk ${ }^{+/+}$without TMPD treatment; black columns, Mdk ${ }^{+/+}$with TMPD treatment. F: Percentages of splenic Th1, Th2, Th17, and

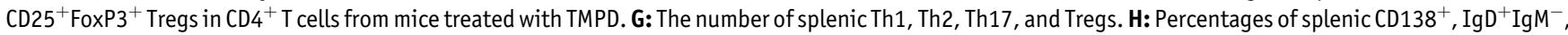
and $\mathrm{IgD}^{+} \mathrm{IgM}^{+}$cells of $\mathrm{B} 220^{+}$cells in lupus splenocytes. Data are expressed as percentages of $\mathrm{CD}^{+} \mathrm{CD}^{+} 9^{+}$cells $(\mathbf{A})$ or means $\pm \mathrm{SEM}(\mathbf{B}) . n=6(\mathbf{B}$ and $\mathbf{E}) ; n=6$ to 8 $(\mathbf{C}$ and $\mathbf{F}) .{ }^{*} P<0.05,{ }^{*} P<0.01$. MK, midkine; No Rx, no TMPD treatment; TMPD, 2,6,10,14-tetramethylpentadecane; Treg, regulatory T cell.

(Figure 4, B and C). In $M d k^{-l-}$ naive $\mathrm{CD}^{+}$T cells exposed to anti-CD3/CD28 Abs in the presence of $300 \mathrm{ng} / \mathrm{mL} \mathrm{MK}$, the frequency of activated $\mathrm{CD} 4{ }^{+} \mathrm{CD} 69^{+} \mathrm{T}$ cells was similar to that in $M d k^{+/+}$T lymphocytes exposed to anti-CD3/ CD28 Abs. We further determined whether MK affects the dephosphorylation and translocation of NFAT into the nucleus, which is closely associated with T-cell subset proliferation in SLE. After exposure to anti-CD3/CD28 Abs, nuclear translocation of NFAT was strikingly lower in $M d k^{-/-}$splenocytes than with either $M d k^{+/+}$splenocytes or $\mathrm{Mdk}^{-/-}$splenocytes treated with recombinant MK protein (Figure 4, D and E). In support of these results, phosphorylation of NFAT in the cytoplasm was prominent in activated $M d k^{-l-} \mathrm{T}$ lymphocytes, whereas supplementation of the cells with recombinant MK protein strikingly inhibited this phenomenon (Figure 4D). IL2 promoter region includes binding elements for NFAT. In proportion to the nuclear activation of NFAT transcription, therefore, IL-2 expression in the supernatant fluid of cultured $\mathrm{T}$ lymphocytes was significantly lower in $M d k^{-/-}$splenocytes than in 


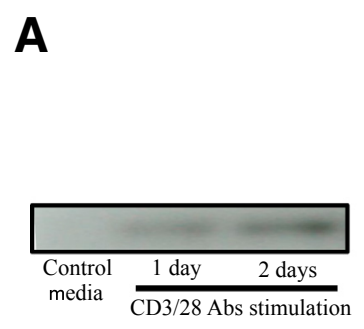

\section{B}

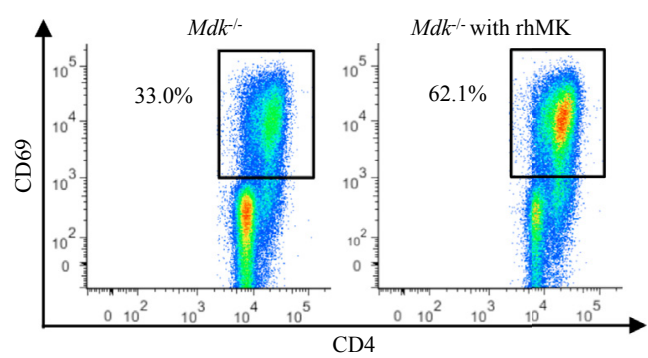

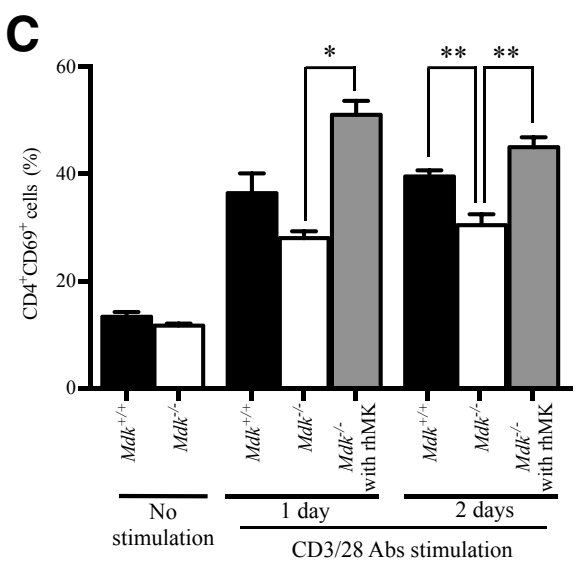

D
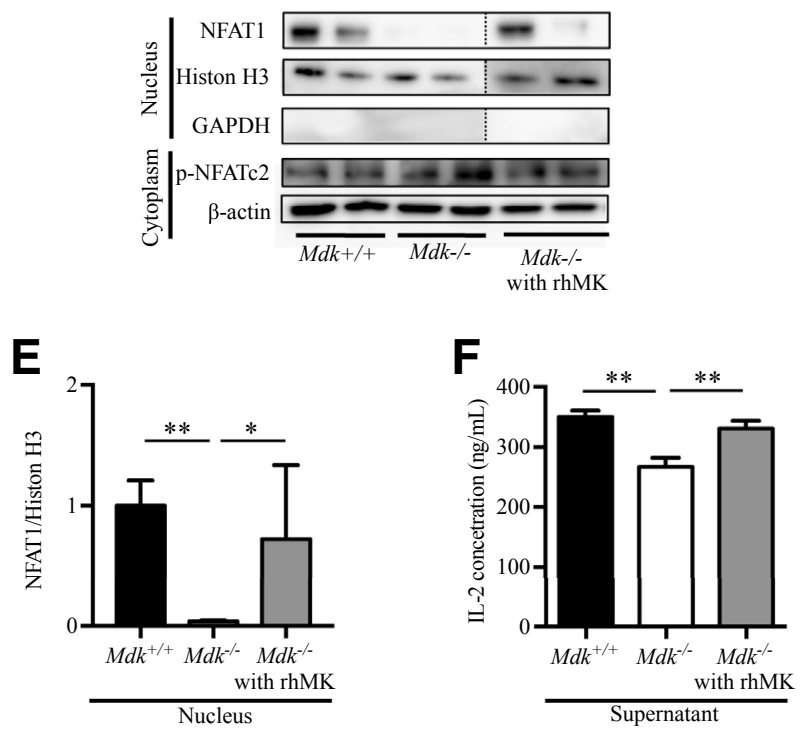

Figure 4 MK deficiency suppresses the NFAT-mediated activation of splenic T lymphocytes treated with anti-CD3/CD28 antibodies in vitro. A: Western blot analysis of MK induction in the supernatant fluid of cultured $\mathrm{Mdk}^{+/+} \mathrm{CD4}^{+} \mathrm{T}$ cells stimulated by anti-CD3/CD28 Abs. B: Representative CD69 staining profile of gated $\mathrm{CD}^{+}{ }^{+} \mathrm{T}$ cells in isolated $\mathrm{Mdk}^{-/-}$splenocytes with/without rhMK after exposure to anti-CD3/CD28 Abs for 2 days. C: Percentage of $\mathrm{CD}^{+}{ }^{+} \mathrm{CD}_{69}{ }^{+}$cells in isolated $\mathrm{CD}^{+} \mathrm{T}$ cells treated with/without rhMK, as described in panel B. Black columns, $\mathrm{Mdk}^{+/+}$; white columns, $\mathrm{Mdk}^{-/-}$; gray columns, $\mathrm{Mdk}^{-/-}$with rhMK. D: Western blot analysis of nuclear NFAT1 and cytoplasmic phospho-NFATc2 expression in activated T splenocytes. E: The intensity of nuclear NFAT1 bands was normalized as to Histone H3. F: ELISA analysis of IL-2 expression in the supernatant fluid of cultured $\mathrm{CD}^{+}{ }^{+} \mathrm{T}$ cells after exposure to anti-CD3/ CD28 Abs at 2 days. Data are expressed as percentages of $\mathrm{CD}^{+} \mathrm{CD}^{+} 9^{+}$cells (B) or means \pm SEM (C). $n=6$ to 10 independent experiments (C); $n=6$ independent experiments (E and $\mathbf{F}) .{ }^{*} P<0.05$, ${ }^{*} P P<0.01$. Ab, antibody; ELISA, enzyme-linked immunosorbent assay; GAPDH, glyceraldehyde-3phosphate dehydrogenase; MK, midkine; NFAT, nuclear factor of activated T cells; $\mathrm{p}$-, phosphorylated rhMK, recombinant midkine.
$M d k^{+/+}$splenocytes and $M d k^{-/-}$splenocytes treated with recombinant MK protein (Figure 4F). MK did not affect $\mathrm{Cn}$ expression during T-cell activation (data not shown). These data suggest that $\mathrm{MK}$ induced activated $\mathrm{CD}^{+}{ }^{+} \mathrm{T}$ cells expressing CD69 through the nuclear activation of NFAT transcription, leading to the promotion of IL-2-associated Th1 cell differentiation.

The molecular network of Th1 cell differentiation involves various essential transcriptional factors, including members of the STAT family induced by various key cytokines. Under conditions of Th1 cell differentiation, the frequency of Th1 cells derived from naive $\mathrm{CD} 4^{+} \mathrm{T}$ cells of $M d k^{+/+}$spleens was significantly higher than that of Th1 cells derived from naive $\mathrm{CD}^{+} \mathrm{T}$ cells of $M d k^{-1-}$ spleens (Figure 5, A and B). Treatment of $M d k^{-l-}$ naive $\mathrm{CD} 4^{+} \mathrm{T}$ cells with the MK protein promoted Th1 cell differentiation, resulting in a Th1 profile similar to that found in $M d k^{+/+}$cells. In contrast, other T-cell subsets such as Th2 and Th17 cells and Tregs were not affected by the presence or absence of the MK protein in the mice under their respective differentiation conditions (data not shown). STAT1 and STAT4 are required for Th1 cell differentiation derived from naive $\mathrm{T}$ cells in response to 100 $\mathrm{ng} / \mathrm{mL}$ IFN- $\gamma$ or $10 \mathrm{ng} / \mathrm{mL}$ IL-12, respectively. We therefore examined the function of MK in the activation of STAT1 and STAT4 in this network. No obvious difference between the two genotypes in response to IFN- $\gamma$ was found in phosphorylation of STAT1 (Figure 5, C and D). Because STAT1 is required for the production of $\mathrm{IgG}$ autoantibodies in the pristine-induced mouse model, ${ }^{34}$ this may cause no significant differences in the titers of $\operatorname{IgG}$ subtypes between the two genotypes. In contrast, treatment with IL-12 for Th1 cell polarization promoted STAT4 phosphorylation in $M d k^{+/+} \mathrm{T}$ cells to a significantly higher degree than in $\mathrm{Mdk}^{-/-} \mathrm{T}$ cells (Figure 5, E and F). The combined data indicated that MK was induced in activated T cells and participated in Th1 cell differentiation as an amplifying factor via promotion of the IL-12/STAT4 signaling (Figure 6).

\section{Discussion}

Activated $\mathrm{T}$ cells play critical roles in adaptive immune responses in diverse organs, which are categorized by the cytokines they produce. ${ }^{5,35}$ Various genetic approaches 
A

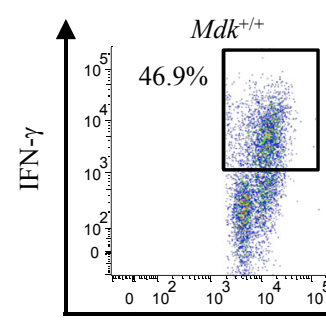

Gated on $\mathrm{CD} 4{ }^{+} \mathrm{T}$ cells

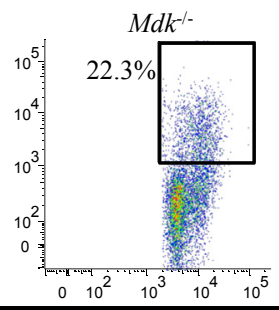

CD4
B

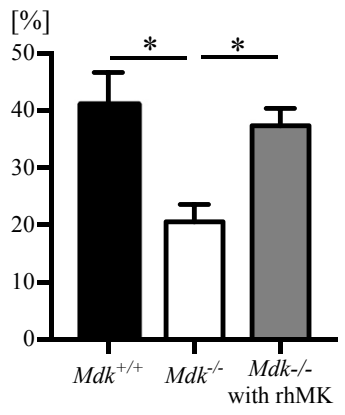

C

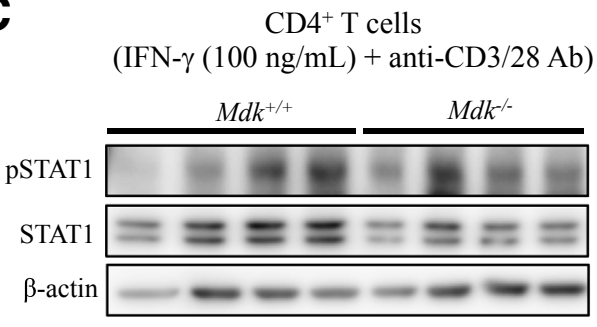

E

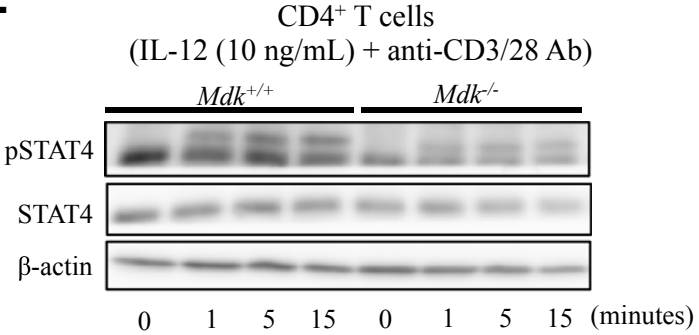

D
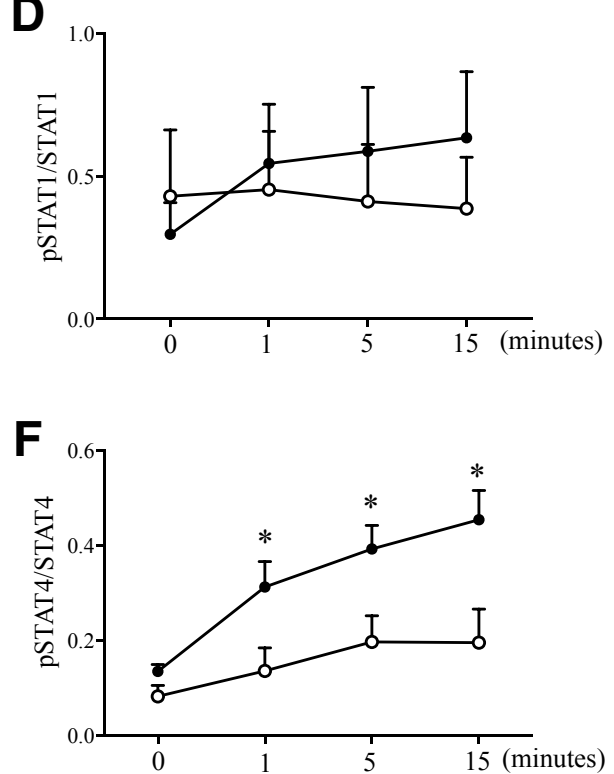

Figure 5 Midkine selectively increases in vitro differentiation of Th1 cells. A: Representative CD4 and IFN- $\gamma$ staining profile in isolated T cells from Mdk ${ }^{+/+}$ mice and $M d k^{-/-}$mice with/without rhMK after exposure to anti-CD3/CD28 Abs for 3 days under Th1 cell-polarizing condition. B: Percentage of CD4 ${ }^{+}$IFN- $\gamma^{+}$ (Th1) cells, as described in panel A. Black columns, $M d k^{+/+}$; white columns, $M d k^{-/-}$; gray columns, $M d k^{-/-}$with rhMK. C: Western blot analysis of the time course of phospho-STAT1 expression in anti-CD3/CD28 Ab-treated CD4 ${ }^{+} \mathrm{T}$ cells from $M d k^{+/+}$and $M d k^{-/-}$mice after their exposure to IFN- $\gamma$. D: Time course of phospho-STAT1 expression normalized to STAT1. Closed circles, $M d k^{+/+}$; open circles, $M d k^{-/-}$. E: Western blot analysis of the time course of phospho-STAT4 expression after their exposure to IL-12. F: Time course of phospho-STAT4 expression. Data are expressed as percentages of CD4 ${ }^{+}$IFN- $\gamma^{+}$cells $(\mathbf{A})$ or means \pm SEM (B). $n=6$ independent experiments (B and F); $n=4$ independent experiments (D). ${ }^{*} P<0.05$. Ab, antibody; IFN, interferon; rhMK, recombinant midkine.

have been applied to demonstrate the importance of the NFAT signaling pathway in the regulation of T-cell proliferation $^{4,7,9}$ and the essential role of members of the STAT family in $\mathrm{T}_{\mathrm{H}}$ cell differentiation. ${ }^{10,36}$ The present study demonstrated that $\mathrm{MK}$ derived from $\mathrm{CD} 4^{+} \mathrm{T}$ cells activates $\mathrm{T}$ splenocytes themselves and Th1 cell differentiation, consequently leading to the exacerbation of glomerular nephritis in SLE. Spontaneous lupus-prone MRL/lpr mice also showed MK induction in the kidneys and spleens (Supplemental Figure S1). MK induction in T cells was indeed found during activation of the $\mathrm{T}$ cells in vitro, and supplementation of $M d k^{-1-}$ activated T cells with the MK protein induced the activation of NFAT signaling and CD69 expression in these cells with a profile similar to that in $\mathrm{Mdk}^{+/+}$activated $\mathrm{T}$ cells (Figure 6A). In addition, MK selectively regulates population and differentiation into Th1 cells through IL-12/STAT4 signaling, which is independent of the Treg population (Figure 6B). Therefore, MK may be involved in a physiological loop that acts as an inducer for expansion of activated $\mathrm{T}$ cells, including Th1 cells, in $\mathrm{LN}$.

Along with an enhanced and accelerated early T-cell response, activated splenic $\mathrm{CD} 4^{+}$or $\mathrm{CD} 4^{-} \mathrm{CD} 8^{-} \mathrm{T}$ cells directly invade organ tissues, including the kidneys, which provides aberrant help to B cells to induce various pathogenic autoantibodies. ${ }^{4}$ The existence of an impaired fine balance between lymphocyte survival and proliferation and altered cytokine production are considered to be responsible for the pathogenesis of LN. In addition to the infiltration of macrophages into injured kidneys, MK indeed enhances the migration of splenic activated $\mathrm{CD} 4^{+} \mathrm{T}$ cells in $\mathrm{LN}$ through the induction of various chemokines and consequently contributes to augmentation of the severity of LN. In SLE T lymphocytes, NFAT plays a central role, not only in lymphocyte tolerance but also in productive activation of 

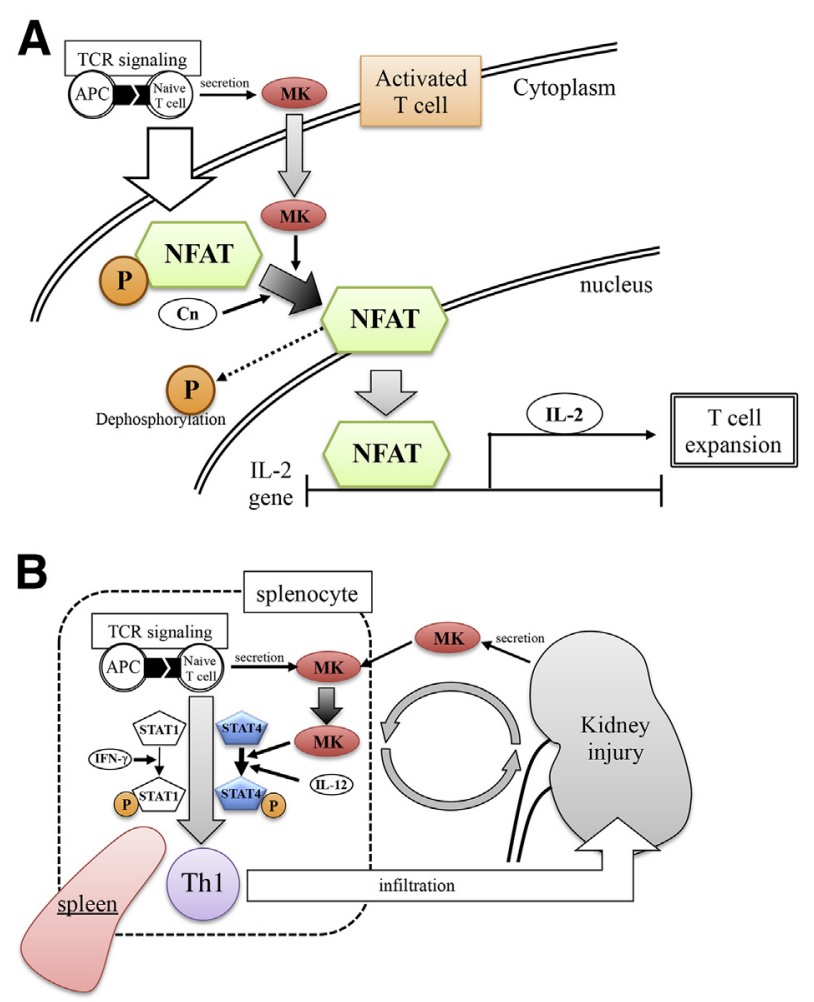

Figure 6 Schematic diagram that shows the possible contribution of midkine (MK) to lupus nephritis. A: MK-induced T-cell expansion through activation of NFAT. B: MK-regulated differentiation of Th1 cells via the IL12/STAT4 signaling in lupus nephritis. APC, antigen-presenting cell; $\mathrm{Cn}$, calcineurin; IFN, interferon; NFAT, nuclear factor of activated T cells; TCR, T-cell receptor.

lymphocytes. ${ }^{4,7}$ On enlargement of the T-cell receptor, activation of $\mathrm{Cn}$ induces dephosphorylation of NFAT in the cytoplasm. Thereafter, dephosphorylated NFAT rapidly translocates into the nucleus where it exerts crucial transcriptional activity to activate downstream targets in the pathogenesis of SLE. In this setting, NFAT also regulates transcription of the polarizing cytokines IFN- $\gamma$ and IL-2 that drive Th1 cell differentiation. In the present study, MK deficiency hampered NFAT nuclear translocation, whereas splenic MK induction facilitated the transcriptional activity of NFAT with the production of various immunomodulatory cytokines. In LN representing a variety of aspects and caused by multiple complex pathogeneses, it would be required for sustainability of the LN pathologic process to enhance and sustain the immune-specific $\mathrm{CD} 4^{+}$T-cell response/differentiation by the induction of potent cytokines in an autocrine or paracrine fashion. Our findings show that activated $\mathrm{T}$ cells and Th1 cell differentiation were up-regulated in an MK-dependent manner together with skewed cytokine production during pathologic exacerbation of $\mathrm{LN}$, revealing a positive amplification circuit for NFAT signaling.

Besides the critical roles of MK in chemotactic activity and subsequent inflammation, ${ }^{12} \mathrm{MK}$ is also involved in immunologic responses in autoimmune diseases. ${ }^{21} \mathrm{MK}$ suppresses IL-2-regulated STAT5 phosphorylation and dendritic cell-mediated $\mathrm{CD}_{4}^{+} \mathrm{CD} 25^{+} \mathrm{FoxP}^{+} \mathrm{T}$ cells (Tregs) through the up-regulation of SH2 domain-containing protein tyrosine phosphatase, leading to the exacerbation of experimental autoimmune encephalomyelitis. ${ }^{21,22}$ Inhibition of $\mathrm{SH} 2$ domain-containing protein tyrosine phosphatase reduces the proliferation of $\mathrm{CD}^{-} \mathrm{CD}^{-} \mathrm{T}$ cells and decreases the production of IFN- $\gamma$ and IL-17A in lupusprone MRL/lpr mice. ${ }^{37}$ In the present study, MK did not affect numbers of $\mathrm{CD} 4^{-} \mathrm{CD} 8^{-} \mathrm{T}$ cells and the production of these cytokines. Dysfunction of Tregs leads to the exacerbation of $\mathrm{LN}$, with a reduction in IL-2 transcription in TMPD-induced LN and in lupus-prone MRL/lpr mice. ${ }^{23,24,38}$ Patients with SLE also show suppression of Tregs and a negative correlation between Tregs and disease activity. ${ }^{2}$ In addition, Amarilyo et al ${ }^{39}$ demonstrate that IL-17 plays an important role for the development of TMPDinduced LN. We therefore determined the involvement of Tregs and Th17 cells in mice with TMPD-induced LN in the present study. Of note, however, no obvious difference in the populations of Tregs and Th17 cells between the two genotypes was found irrespective of enhanced Th1 cell differentiation in $M d k^{+/+} \mathrm{LN}$ mice. As demonstrated in studies of Suzumura and colleagues, ${ }^{21,22}$ MK might regulate the development of Tregs in an IL-2-dependent manner. Because exacerbation of $\mathrm{LN}$ shows a striking reduction in IL-2 transcription, ${ }^{23,24}$ MK might not affect Treg population and the subsequent Th17 populations in the present study. In general, Th1 cell differentiation in LN is accompanied by IFN- $\gamma /$ STAT1 and IL-12/STAT4 signaling. Consequently, MK selectively phosphorylated IL-12/STAT4 signaling to promote Th1 cell differentiation but not phosphorylated IFN- $\gamma /$ STAT1 signaling. Many basic and clinical studies to date have demonstrated that IFN- $\gamma /$ STAT1 activation is also required for the pathogenesis of $\mathrm{LN}{ }^{40-44}$ Given these facts, diverse mechanism of $\mathrm{LN}$ involves inappropriate tissue homing of T lymphocytes, including Th1, Th17, and Tregs, through the dysfunction of STAT family signaling. The association of variations in the STAT4 gene in LN with severe renal insufficiency has been demonstrated. ${ }^{45}$ Although a STAT4-specific blockade ameliorates LN disease activity in MRL/lpr mice with advanced nephritis, ${ }^{46}$ transgenic STAT4 knockout mice showed more severe nephritis. ${ }^{47}$ Knockout of STAT4 may cause either incomplete STAT inhibition or complementary activation of another pathway in the absence of STAT4 signaling. Therefore, direct or complete suppression of STAT4 signaling makes it difficult to design a therapeutic strategy without side effects. In addition, MK has also been demonstrated to serve as a regulator of mature B-cell survival in B-cell lymphoma. ${ }^{48}$ In the present study, $M d k^{-I-}$ mice did not show any immune-complex deposition in subepithelial areas, which was previously reported. ${ }^{49} \mathrm{MK}$ may affect humoral immunity through activation of $\mathrm{T}$ cells in TMPD-induced LN. Thus, MK may mediate STAT4associated differentiation of Th1 cells in the pathogenesis of LN, but it may not affect Tregs. 
To the best of our knowledge, a hyperactive Cn-NFAT pathway plays an essential role in such signaling for LN. Indeed, the Cn inhibitors, FK506 tacrolimus and cyclosporine A, are highly effective in blocking this signaling in SLE T cells. However, this therapeutic strategy has several side effects, including hypertension, hyperglycemia, and renal toxicity. To date, MK blockade has been shown to improve hypertension in ischemic renal injury through regulation of the renin-angiotensin system. ${ }^{31,32}$ Accordingly, an MK-regulated device may lead to a reduction in toxicity from LN therapy. Herein, to our knowledge, we demonstrated for the first time that MK induces NFATregulated activation of $\mathrm{T}$ cells and Th1 cell differentiation through IL-12/STAT4 signaling, leading to the exacerbation of LN (Figure 6). This study of MK thus provides novel insights into LN that may open new avenues and facilitate research on the cause and the development of therapeutics for LN.

\section{Acknowledgments}

We thank Noriyuki Suzuki, Naoko Asano, and Yuriko Sawa for their excellent technical assistance and Hitomi Aoyama for secretarial assistance.

\section{Supplemental Data}

Supplemental material for this article can be found at http://dx.doi.org/10.1016/j.ajpath.2016.12.006.

\section{References}

1. Tsokos GC: Systemic lupus erythematosus. N Engl J Med 2011, 365: 2110-2121

2. Liu Z, Davidson A: Taming lupus-a new understanding of pathogenesis is leading to clinical advances. Nat Med 2012, 18:871-882

3. Crispin JC, Kyttaris VC, Terhorst C, Tsokos GC: T cells as therapeutic targets in SLE. Nat Rev Rheumatol 2010, 6:317-325

4. Kyttaris VC, Zhang Z, Kampagianni O, Tsokos GC: Calcium signaling in systemic lupus erythematosus T cells: a treatment target. Arthritis Rheum 2011, 63:2058-2066

5. Tucci M, Ciavarella S, Strippoli S, Dammacco F, Silvestris F: Oversecretion of cytokines and chemokines in lupus nephritis is regulated by intraparenchymal dendritic cells: a review. Ann N Y Acad Sci 2009, 1173:449-457

6. Macian F, Garcia-Cozar F, Im SH, Horton HF, Byrne MC, Rao A: Transcriptional mechanisms underlying lymphocyte tolerance. Cell 2002, 109:719-731

7. Macian F: NFAT proteins: key regulators of T-cell development and function. Nat Rev Immunol 2005, 5:472-484

8. Fujii Y, Fujii K, Iwata S, Suzuki K, Azuma T, Saito K, Tanaka Y: Abnormal intracellular distribution of NFAT1 in T lymphocytes from patients with systemic lupus erythematosus and characteristic clinical features. Clin Immunol 2006, 119:297-306

9. Fric J, Zelante T, Wong AY, Mertes A, Yu HB, Ricciardi-Castagnoli P: NFAT control of innate immunity. Blood 2012, 120:1380-1389

10. Goropevšek A, Holcar M, Avcin T: The role of STAT signaling pathways in the pathogenesis of systemic lupus erythematosus. Clin
Rev Allergy Immunol 2016. [Epub ahead of print] doi:10.1007/ s12016-016-8550-y

11. Muramatsu T: Midkine and pleiotrophin: two related proteins involved in development, survival, inflammation and tumorigenesis. J Biochem 2002, 132:359-371

12. Kosugi T, Sato W: Midkine and the kidney: health and diseases. Nephrol Dial Transplant 2012, 27:16-21

13. Kadomatsu K, Muramatsu T: Midkine and pleiotrophin in neural development and cancer. Cancer Lett 2004, 204:127-143

14. Yoshida Y, Goto M, Tsutsui J, Ozawa M, Sato E, Osame M, Muramatsu T: Midkine is present in the early stage of cerebral infarct. Brain Res Dev Brain Res 1995, 85:25-30

15. Yoshida Y, Ikematsu S, Moritoyo T, Goto M, Tsutsui J, Sakuma S, Osame M, Muramatsu T: Intraventricular administration of the neurotrophic factor midkine ameliorates hippocampal delayed neuronal death following transient forebrain ischemia in gerbils. Brain Res 2001, 894:46-55

16. Horiba M, Kadomatsu K, Nakamura E, Muramatsu H, Ikematsu S, Sakuma S, Hayashi K, Yuzawa Y, Matsuo S, Kuzuya M, Kaname T, Hirai M, Saito H, Muramatsu T: Neointima formation in a restenosis model is suppressed in midkine-deficient mice. J Clin Invest 2000, 105:489-495

17. Maruyama K, Muramatsu H, Ishiguro N, Muramatsu T: Midkine, a heparin-binding growth factor, is fundamentally involved in the pathogenesis of rheumatoid arthritis. Arthritis Rheum 2004, 50: 1420-1429

18. Sato W, Kadomatsu K, Yuzawa Y, Muramatsu H, Hotta N, Matsuo S, Muramatsu T: Midkine is involved in neutrophil infiltration into the tubulointerstitium in ischemic renal injury. J Immunol 2001, 167: 3463-3469

19. Kosugi T, Yuzawa Y, Sato W, Kawai H, Matsuo S, Takei Y, Muramatsu T, Kadomatsu K: Growth factor midkine is involved in the pathogenesis of diabetic nephropathy. Am J Pathol 2006, 168:9-19

20. Kosugi T, Yuzawa Y, Sato W, Arata-Kawai H, Suzuki N, Kato N, Matsuo S, Kadomatsu K: Midkine is involved in tubulointerstitial inflammation associated with diabetic nephropathy. Lab Invest 2007 87:903-913

21. Wang J, Takeuchi H, Sonobe $\mathrm{Y}$, Jin S, Mizuno T, Miyakawa S, Fujiwara M, Nakamura Y, Kato T, Muramatsu H, Muramatsu T, Suzumura A: Inhibition of midkine alleviates experimental autoimmune encephalomyelitis through the expansion of regulatory $\mathrm{T}$ cell population. Proc Natl Acad Sci U S A 2008, 105:3915-3920

22. Sonobe $\mathrm{Y}$, Li H, Jin S, Kishida S, Kadomatsu K, Takeuchi H, Mizuno T, Suzumura A: Midkine inhibits inducible regulatory T cell differentiation by suppressing the development of tolerogenic dendritic cells. J Immunol 2012, 188:2602-2611

23. Lieberman LA, Tsokos GC: The IL-2 defect in systemic lupus erythematosus disease has an expansive effect on host immunity. J Biomed Biotechnol 2010, 2010:740619

24. Moulton VR, Tsokos GC: T cell signaling abnormalities contribute to aberrant immune cell function and autoimmunity. J Clin Invest 2015, $125: 2220-2227$

25. Nakamura E, Kadomatsu K, Yuasa S, Muramatsu H, Mamiya T, Nabeshima T, Fan QW, Ishiguro K, Igakura T, Matsubara S, Kaname T, Horiba M, Saito H, Muramatsu T: Disruption of the midkine gene (Mdk) resulted in altered expression of a calcium binding protein in the hippocampus of infant mice and their abnormal behaviour. Genes Cells 1998, 3:811-822

26. Maeda K, Kosugi T, Sato W, Kojima H, Sato Y, Kamimura D, Kato N Tsuboi N, Yuzawa Y, Matsuo S, Murakami M, Maruyama S, Kadomatsu K: CD147/basigin limits lupus nephritis and Th17 cell differentiation in mice by inhibiting the interleukin-6/STAT-3 pathway. Arthritis Rheumatol 2015, 67:2185-2195

27. Weening JJ, D'Agati VD, Schwartz MM, Seshan SV, Alpers CE, Appel GB, Balow JE, Bruijn JA, Cook T, Ferrario F, Fogo AB, Ginzler EM, Hebert L, Hill G, Hill P, Jennette JC, Kong NC, Lesavre P, Lockshin M, Looi LM, Makino H, Moura LA, Nagata M: 
The classification of glomerulonephritis in systemic lupus erythematosus revisited. J Am Soc Nephrol 2004, 15:241-250

28. Maeda-Hori M, Kosugi T, Kojima H, Sato W, Inaba S, Maeda K, Nagaya H, Sato Y, Ishimoto T, Ozaki T, Tsuboi N, Muro Y, Yuzawa Y, Imai E, Johnson RJ, Matsuo S, Kadomatsu K, Maruyama S: Plasma CD147 reflects histological features in patients with lupus nephritis. Lupus 2014, 23:342-352

29. Kosugi T, Heinig M, Nakayama T, Connor T, Yuzawa Y, Li Q, Hauswirth WW, Grant MB, Croker BP, Campbell-Thompson M, Zhang L, Atkinson MA, Segal MS, Nakagawa T: Lowering blood pressure blocks mesangiolysis and mesangial nodules, but not tubulointerstitial injury, in diabetic eNOS knockout mice. Am J Pathol 2009, 174:1221-1229

30. Kato N, Kosugi T, Sato W, Ishimoto T, Kojima H, Sato Y, Sakamoto K, Maruyama S, Yuzawa Y, Matsuo S, Kadomatsu K: Basigin/CD147 promotes renal fibrosis after unilateral ureteral obstruction. Am J Pathol 2011, 178:572-579

31. Hobo A, Yuzawa Y, Kosugi T, Kato N, Asai N, Sato W, Maruyama S, Ito Y, Kobori H, Ikematsu S, Nishiyama A, Matsuo S, Kadomatsu K: The growth factor midkine regulates the renin-angiotensin system in mice. J Clin Invest 2009, 119:1616-1625

32. Sato Y, Sato W, Maruyama S, Wilcox CS, Falck JR, Masuda T, Kosugi T, Kojima H, Maeda K, Furuhashi K, Ando M, Imai E, Matsuo S, Kadomatsu K: Midkine regulates BP through cytochrome P450-derived eicosanoids. J Am Soc Nephrol 2015, 26: $1806-1815$

33. Tucci M, Stucci S, Strippoli S, Silvestris F: Cytokine overproduction, T-cell activation, and defective T-regulatory functions promote nephritis in systemic lupus erythematosus. J Biomed Biotechnol 2010, 2010:457146

34. Thibault DL, Chu AD, Graham KL, Balboni I, Lee LY, Kohlmoos C, Landrigan A, Higgins JP, Tibshirani R, Utz PJ: IRF9 and STAT1 are required for $\mathrm{IgG}$ autoantibody production and $\mathrm{B}$ cell expression of TLR7 in mice. J Clin Invest 2008, 118:1417-1426

35. Zhu J, Yamane H, Paul WE: Differentiation of effector CD4 T cell populations (*). Annu Rev Immunol 2010, 28:445-489

36. Oestreich KJ, Weinmann AS: Transcriptional mechanisms that regulate T helper 1 cell differentiation. Curr Opin Immunol 2012, 24: 191-195

37. Wang J, Mizui M, Zeng LF, Bronson R, Finnell M, Terhorst C, Kyttaris VC, Tsokos GC, Zhang ZY, Kontaridis MI: Inhibition of
SHP2 ameliorates the pathogenesis of systemic lupus erythematosus. J Clin Invest 2016, 126:2077-2092

38. de Zubiria Salgado A, Herrera-Diaz C: Lupus nephritis: an overview of recent findings. Autoimmune Dis 2012, 2012:849684

39. Amarilyo G, Lourenco EV, Shi FD, La Cava A: IL-17 promotes murine lupus. J Immunol 2014, 193:540-543

40. Richards HB, Satoh M, Jennette JC, Croker BP, Yoshida H, Reeves WH: Interferon-gamma is required for lupus nephritis in mice treated with the hydrocarbon oil pristane. Kidney Int 2001, 60:2173-2180

41. Martinez-Lostao L, Ordi-Ros J, Balada E, Segarra-Medrano A, MajoMasferrer J, Labrador-Horrillo M, Vilardell-Tarres M: Activation of the signal transducer and activator of transcription-1 in diffuse proliferative lupus nephritis. Lupus 2007, 16:483-488

42. Wang S, Yang N, Zhang L, Huang B, Tan H, Liang Y, Li Y, Yu X: Jak/STAT signaling is involved in the inflammatory infiltration of the kidneys in MRL/lpr mice. Lupus 2010, 19:1171-1180

43. Lee SK, Silva DG, Martin JL, Pratama A, Hu X, Chang PP, Walters G, Vinuesa CG: Interferon-gamma excess leads to pathogenic accumulation of follicular helper T cells and germinal centers. Immunity 2012, 37:880-892

44. Liang Y, Xu WD, Yang XK, Fang XY, Liu YY, Ni J, Qiu LJ, Hui P, Cen H, Leng RX, Pan HF, Ye DQ: Association of signaling transducers and activators of transcription 1 and systemic lupus erythematosus. Autoimmunity 2014, 47:141-145

45. Bolin K, Sandling JK, Zickert A, Jonsen A, Sjowall C, Svenungsson E, Bengtsson AA, Eloranta ML, Ronnblom L, Syvanen AC, Gunnarsson I, Nordmark G: Association of STAT4 polymorphism with severe renal insufficiency in lupus nephritis. PLoS One 2013, 8:e84450

46. Menke J, Bork T, Kutska B, Byrne KT, Blanfeld M, Relle M, Kelley VR, Schwarting A: Targeting transcription factor Stat4 uncovers a role for interleukin-18 in the pathogenesis of severe lupus nephritis in mice. Kidney Int 2011, 79:452-463

47. Singh RR, Saxena V, Zang S, Li L, Finkelman FD, Witte DP, Jacob CO: Differential contribution of IL-4 and STAT6 vs STAT4 to the development of lupus nephritis. J Immunol 2003, 170:4818-4825

48. Cohen S, Shachar I: Midkine as a regulator of B cell survival in health and disease. Br J Pharmacol 2014, 171:888-895

49. Satoh M, Kumar A, Kanwar YS, Reeves WH: Anti-nuclear antibody production and immune-complex glomerulonephritis in BALB/c mice treated with pristane. Proc Natl Acad Sci U S A 1995, 92: $10934-10938$ 